\title{
Relationship between Personality Traits and Sense of Urgency: A Study of Repso Malaysia
}

\author{
Hartini Ahmad ${ }^{1}$ and Johari Jalil ${ }^{2}$ \\ ${ }^{1}$ School of Business Management, Universiti Utara, Malaysia \\ ${ }^{2}$ Center for University-Industry Collaboration, Universiti Utara, Malaysia
}

Correspondence should be addressed to: Hartini Ahmad; hartini@uum.edu.my

Received 9 October 2011; Accepted 2 June 2013; Published 28 November 2013

Academic Editor: Muhammad Suhaizan Sulong

Copyright @ 2013 Hartini Ahmad and Johari Jalil. Distributed under Creative Commons CC-BY 3.0

\begin{abstract}
Sense of urgency is a crucial element of a successful change process. This research was designed to investigate the relationship between personality traits and sense of urgency. It employed quantitative method in examining the said relationship against a real-life scenario of major change in a single entity of a Multi National Corporation - Repso Malaysia. Through on-line questionnaire, a total of 247 employees of various functions, job levels and cross border cultures made up the case study of this research. The findings of the research confirmed the positive relationship of conscientiousness, extraversion, agreeableness and openness to experiences with sense of urgency. The trait of neuroticism revealed a negative but non-significant relationship to sense of urgency and duly supported with justification by the research. The paper addresses the limitations; first, the use of modified instrument lacks the established knowledge of its validity and reliability within the contexts of the case organization. Secondly, the researcher has no control on who actually responds to the questions. Thirdly, the research sample represents only single entity and cannot be generalized to the total population. Other than contributing to the body of knowledge over a subject which is empirically scarce, the research further renewed the importance of micro level analysis of an organization i.e. individuals rather than only the macro level.
\end{abstract}

Keywords: Change, Sense of Urgency, Personality Traits, MNCs.

\section{Introduction}

Against the backdrop of an increasing trend of globalization, coupled with an imminent indication of a prolonged global economy slow-down, management of change is taking center-stage on business leader's set of priorities. Change can come in many ways such as total quality management (TQM), redesign, restructuring or right sizing, as well as the radical ones like business reengineering, behavioral and cultural change, and business turnaround (Ahmad, Francis, and Zairi, 2007; Kotter, 1996a; TaylorBianco, 2006; Stanleigh, 2008). In whatever forms it comes, the desired outcome of change remains intact that is, to make the

Cite this Article as: Hartini Ahmad and Johari Jalil (2013), "Relationship between Personality Traits and Sense of Urgency: A Study of Repso Malaysia," IBIMA Business Review, Vol. 2013 (2013), Article ID 126696, DOI: $10.5171 / 2013.126696$ 
organization stronger and more resilient to the dynamics of the operating environment.

\section{Change Efforts}

Despite of the overwhelming call for change, the statistics demonstrated that most change efforts fails to achieve its desired outcome. The studies indicated that failure rate was approximately up to $70 \%$ (e.g. Hertog et al., 2010; Raineri, 2009). The latter cited example, Riva (Video Company) faced failure at the first stage of ensuring employees aware of the new direction of the company. Both studies highlighted the importance for the management in receiving support from all level of employees. A potential consequence of such failed attempts was that only a few people believed that change was really needed and was going to happen.

Other examples of major change failures include mega-mergers such AOL-Time Warner in the year 2001; Daimler Benz Chrysler in 2003; Hewlett Packard - Compaq and Alcatel-Lucent in the year 2005, which features, among others, key down-lights of failure to raise the sense of awareness and buy-ins from employees over the need to embrace change which in return leads to loss of productivity and low retention of skills (Tobak, 2009).

This is in addition to the overall consensus that change efforts are costly and disruptive. Kilpatrick (1999) asserted that business leaders need to painfully weigh the cost and benefit analysis of a major change as the 'cost' will likely outweigh the short-term solutions. 'When in doubt-don't!'. In most arguments, people in relation to their behavior and reaction to changes, are blamed on change failures (Kotter, 1995; Kotter and Cohen, 2002; Kotter and Margolis, 1996). Such is the dilemma of change; to change while knowing the high likelihood of failure or not to change; and face the possibility of becoming extinct in a dynamic market.

\section{Sense of Urgency}

Most of previous researches on organizational change were focused on macro organization factors such as organization competencies, knowledge retentions and structure with very few indulging on person oriented studies i.e. people behavioral aspect as a catalyst or key enabler of change (Judge, Higgins, Thoresen and Barrick, 1999; Vakola, Tsausis and Nikolaou, 2004).

Minimum attention has been paid to the definition and measurement of people commitment within a change context, and there is virtually no empirical evidence to substantiate the claims made about its effects (Herscovitch and Meyer, 2002). According to previous researches, components of attitude and commitment of change encompass vision creation, empowerment, communication and mobilization of resources (Todnem, 2007; Herscovitch and Meyer, 2002; Kotter, 1996b; Kotter and Cohen, 2002).

This paper aims to narrow the scope on sense of urgency, which is argued to have relationship with the individual traits (Kotter, 1996b; Kotter and Cohen, 2002), and is the most important phase to be investigated at the early stage of change (Stanleigh, 2008). Without the right energy and comprehension of the need to change of the employees which leads to the sense of urgency, the need to change would be futile. Hence, the connection of other constructs to the sense of urgency is very crucial, which then enable firm to gauge the level of sense of urgency as a prediction to change success (Paton, Beranek and Smith, 2008).

The description of sense of urgency from various scholars can be summarized as in Table 1. 
Table 1: Conceptual Definitions for Sense of Urgency

\begin{tabular}{|l|l|}
\hline Author & Conceptual Definition \\
\hline Kotter(1995;1996a) & Business as usual is unacceptable \\
\hline Harari (1995) & Shaking people out of their comfort zone \\
\hline Belasco (1990) & one's personal interests to take on the challenges suggested by change \\
\hline Covington ( 2001) & The wide spread belief that if we do not change our ways and soon, we may die. \\
\hline Rogers et al. (2003) & A hunger for promotion to a higher performance league, or division. \\
\hline \multicolumn{2}{l}{ (Source: Researcher) }
\end{tabular}

In many literatures, inverse definitions of sense of urgency were articulated. The two most common inverse definitions are panic and complacency. Provoking a panic response in the organization does produce the same result or the same level of energy, or call to action, which is a true sense of urgency. Panic can be characterized by kneejerk, 'cover your rear' behavior (Harari, 1995). This sudden energy level and behavior is not permanent and will be reverted to its normal state as soon as the pressure is off. Similar to panic is anxiety, which also produces only short-term results. Instead, anxiety has the added dimension of driving people deep into the negative behavior of resisting the change initiative (Belasco, 1990; Kotter and Margolis, 1996).

Panic and anxiety are part of the definition of the Big 5 of neuroticism that the researcher predicts to have association with the sense of urgency.

The current research agrees that complacency is the antithesis of sense of urgency (Kahne, 2005). Where sense of urgency is the feeling by the members of an organization that they must do something now, complacency is the feeling by the organization that there is no reason to do anything differently. Merriam-Webster (2003) defined complacency as selfsatisfaction accompanied by unawareness of actual dangers or deficiencies. Where sense of urgency is proclivity to action, complacency is a proclivity to inaction. This self-satisfaction is driven by false pride, arrogance, or ignorance (Kotter and Cohen, 2002). Here the task of 'burning the platform'
(Kotter, 1996a; Paton et al., 2008) becomes extremely challenging.

Complacency is further exacerbated in organizations that have seen too many change programs or initiatives that never yielded significant result. Some organizations are simply tired of the constant parade of new techniques and they lack interest in trying something else (Hoyle, 2010). Repeated cycles of calm - crisis can lead to long -term organizational complacency that will derail efforts and produce an organization that is numb to change (Harari, 1995; Kotter, 2008).

Kotter (1996b) in his renowned '8 phases of change' theory asserted clearly the importance of completing the $1^{\text {st }}$ Phase of Change; Creating Sense of Urgency prior to the rest of phases. This is in support by the evergreen 'Lewin's Theory of Change' which places 'unfreezing' as the crucial stage of change process. The step in provoking sense of urgency i.e. the compelling reason to move away from the state of inertia (Covington, 2001) can be associated with the process of unfreezing i.e. breaking down the status quo. Both senses of urgency and the steps of unfreezing can be invoked upon an emergence of crisis - either real or made-up as stated by Lewin in 1951(Burnes, 2004). However, there is a lack of studies investigate the personality traits to see the link with the sense of urgency in one single case, a Multi National Corporation (MNC) in particular.

Kotter's 'Eight steps of Change Model' (Kotter, 1996a,b) has been the guiding principles in change planning. The 
recommended steps and the core challenges are as follow:

\section{1) Establish a sense of urgency}

Create a burning bridge and get people out of the bunker

\section{2) Create a guiding coalition}

Get the right people in place with trust, emotional, commitment and teamwork to guide the difficult change process

\section{3) Develop a vision and strategy}

Get the team to create the right vision and strategies to guide all the remaining stages of change.

4) Communicate changed vision

Get as much 'buy-in' as possible

\section{5) Empower broad based action}

Remove key obstacles that stop people form acting on the vision

6) Create short term wins

Produce enough short term/quick gains to energize people and enlighten the pessimist

7) Consolidate and produce change

Continue the pace of change without stopping for any obstacles

8) Anchor new approaches

Create supporting structure to provide roots for the new ways of operating

Kotter (1996b) warned that establish sense of urgency is paramount and absolutely antecedent to the rest of the steps. If it fails, the rest of the steps become rhetorical.

\section{Personality Traits and Sense of Urgency}

A study done by Kahne (2005) investigated the relationship of the sense of urgency with the Big Five personality constructs (five factor model - FFM) also known as Big 5. Big Five personality constructs were adopted as a tool due its undisputed accreditation as an enabler in understanding of the relation between personality studies and important organizational criteria (Matzler, Renzl, Müller, Herting and Mooradian, 2008; Roth and Collani, 2000). The FFM is also an appropriate framework in studying individual differences and attitudes toward organizational change (Vakola et al., 2004).

The resolution on whether personality constructs can be used as a predictor to sense of urgency is too important to be ignored. The ability to determine the level of sense of urgency among individuals will enable an organization to review and strategize its effort before embarking into an expensive and volatile change initiatives (Kotter, 1996b; Walker, Armenakis and Berneth, 2007).

Hence, this paper presents the relationship of personality constructs as predicting tools on sense of urgency. As constantly asserted by scholars (Tallman, 2007; Vakola, 2004; Judge, 1999), a person's personality is very stable over time, hence, making the constructs reliable and sustainable predictor for us to include on the theoretical frame work. Because of its validity and wide acceptance the Big Five of personality traits have been extensively utilized in recent organizational and other applied research (e.g. Hurtz and Donovan, 2000; Judge et al., 1999; Judge et al., 2002; Salgado, 1997). Clearly, none of these explanations is fully satisfactory, none is sufficient by itself to rationalize the relationship of the personality traits and the sense of urgency.

To my best knowledge, there are no further researches done on the subject of sense of urgency and its relation to personality's traits apart from Kahne in 2005. The closest research on the subject was performed by Maria Vakola, a specialist in personality studies, who examined the relationship between the Big Five personality constructs and attitude for change in 2004.

This paper is motivated due to the exhaustiveness of the parameters to the 
sense of urgency coupled with the inconclusiveness findings of previous researches.

\section{Gaps in the Previous Research}

It is observed that there is a lack of sense of urgency among employees in many organizations which were embarking change. A Business Intelligence Study published in 1998, concluded that 7 out of 10 change efforts that are critical to organizational success failed to achieve the intended goal (Miller, 2002), this also supported by Ahmad et al., (2007). He further quoted another 2000 review that $28 \%$ of change initiatives were discarded before completion, $46 \%$ fall behind schedule or run over budget and $80 \%$ are mismatched with the predetermined objectives. Kotter (1996b) quoted that fewer than 15 of the 100 (around only 15\%) or more companies did the change successfully. Higgs and Rowland (2001) concluded that merely $30 \%$ of change initiatives meet expectation.

Two previous researches, Kahne (2005) and Vakola (2004), determine the relationship between personality traits and attitude to change yield conflicting result. It is deemed that a person with high sense of urgency (to change) will synonymously have similar level of positive attitude to change. Kahne (2005) was not able to prove the relationship between personality traits (FFM) and sense of urgency. On the other hand Vakola (2004) found significant relationship between similar constructs of personality traits with attitude of change. Mitchell and Jolley (1992) urged a repeat study on previous researches that yield conflicting results.

There were few apparent gaps observed in both Kahne and Vakola's work. Kahne's respondents were made of random sampling from various entities in Unites States including students and non-profitable organizations. On the other hand, Vakola's respondents were entirely made of participants of a single organized seminar from various organizations in Greece. Other than the argument of cultural ideology biases (Woerkum, Aarts, and Grip, 2009), both researches, as stated in their declaration of study limitation, were not able to test their hypotheses against a single entity embarking on change (Hofstede, 1980; Mowen, et al., 2007; Nadler and Tushman, 1980). In the effort to address the gap from the works of Kahne and Vakola, this research focusing on multi-functions respondents of a single entity which is Repso Malaysia.

Clark (2007) posited that this dissatisfaction (with the status quo) must be genuine or true enough to bring about a condition requiring immediate action. Kotter (2008) suggested that urgency is a problem when it is not a combination of thoughts feelings and actions that lead to removing complacency. Thoughts of urgency alone, according to Kotter, are insufficient and considered false urgency without action.

Sense of urgency has frequently been argued as the very first step in ensuring change success (Bacon, 2003; Kahne, 2005; Kotter, 1996b, 2008; Roger, Shannon and Gent, 2003), therefore it needs to be triggered into employees by identifying such factors that lead to it (Hoyle, 2010; Russel and Russel, 2006).

According to Kotter (1996b), one of the main factors that prevents sense of urgency and prevents people from taking action is complacency - people get too comfortable with the way things are done and don't see, or feel, the need to change. The research perspective states that there is the need to tackle the issue by triggering 'sense of urgency' into people. In the context of this research - how do the personality traits related to the sense of urgency?

\section{Hypotheses Development}

From the previous studies (for example: Costa and McCrae, 1992; Judge and Bono, 2000; Judge et al., 2002; Raja et al., 2004), the 
researcher offers the following statement of the hypotheses:

Hypothesis 1: Neuroticism is negatively related to sense of urgency.

Costa and McCrae (1992) reported that persons high in neuroticism are anxious, agitated and depressed in nature. Neurotics often serve as poor team performers, have a tendency to be subversive and view the need for change negatively (Mowen et al., 2007; Vakola et al., 2004). Raja, Johns and Ntalianis (2004) argued that neurotic employees will avoid situations requiring long-term commitment, social skills, trust, and taking initiative. The above arguments relate employees high in neuroticism as low commitment workers and would not be reliant in producing above expectation. Neurotics are likely to be adverse to job mobility, as they would be of changing organizations.

Whether this is connected to sense of loyalty to the organization is not determined. It is not expected that neuroticism and employees' obligation to serve the needs of the organization will be correlated.

Hypothesis 2: Extraversion is positively related to sense of urgency.

Extroverts are outspoken, proactive and cherish challenges (Costa and McCrae, 1992). Raja et al., (2004) found that extroversion was directly related to relational contracts and inversely related to transactional contracts indicating extroverted employees tend to seek long term employment and are committed to it. Extroverts will develop a high sense of belonging and have a high standard of self expectation of both individual and group that they participate in. People high in extroversion also have a bias towards status, recognition and power (Costa and McCrae, 1992). These employees tend to be ambitious and are in constant look out for opportunity of recognition and career development. There are not adverse to risk taking and further labors expectation for the organization to support their determined enablers towards the objectives.

Hypothesis 3: Openness is positively related to sense of urgency.

People who are high in openness invite new experiences (Costa and McCrae, 1992). High openness employees seek assignment with stretched targets and expect rewards and recognition when achieving their targets (O'Neill and Xiao, 2009; Strang and Kuhnert, 2009). People who are open have a high need for autonomy and tend to be creative, adaptive and accepting of change.

They have a low level of deference to others (Costa and McCrae, 1992). Employees who are high in openness would not be motivated with mundane activities and low-profile jobs. They are resourceful and innovative.

Hypothesis 4: Agreeableness is positively related to sense of urgency.

People who are high on openness appear to work at developing good interpersonal relations and participating in decisions (Nikolaou, 2003; Mowen et al., 2007; O'Neill and Xiao, 2009; Strang and Kuhnert, 2009).

Hypothesis 5: Conscientiousness is positively related to sense of urgency.

Raja et al., (2004) found that employees high in conscientiousness choose relational contracts which indicate that conscientious employees are concerned with developing long term relationships with the organization. As indicated above, they found employees high in conscientiousness choose relational contracts but not transactional contracts. These findings revealed that conscientious employees know intimately their career direction and are very objective on their purpose. Very aware of their own competencies and weakness, these employees will expect the organization to reciprocate their good outputs with adequate 
trainings, promotion opportunities suitable as a valued employee. They tend to be dependent and would not need much personal attention. Ironically, most of the organizational change literatures fail to distinguish between the diversity of participants in change programs, treating them as a single entity (Lewis et al., 2006; Strang and Kuhnert, 2009).

\section{Case Study Organization}

The need to understand and explain the complex sense of urgency which is suited to research problems, is best applied when the phenomenon of interest cannot be distinguished from its context and must be seen within a context (George and Bennet, 2005; Yin, 2003). This lead the current researcher to use the case study approaches i.e. the single entity study. Furthermore, it allows the researcher to internalize a real-life scenario of change in which the particular event has occurred.

Status quo in Repso will result in decline in sales in the range of $20 \%$ annually. This will put severe constraint in earnings and have imminent impact on continuous investment on both growth capital and maintenance (average around US $\$ 5$ million annually). The company will be forced to prepare an exit strategy and will impact 123 employees and 220 company appointed distributors not to mention the possible severe reputational impact to Repso as an international company. Much has been said in creating a 'burning platform' in the quest to trigger the sense of urgency. In this context, the burning platform comes is the imminent change in technology and possible shift in consumer demand attracted by a cheaper alternative of fuel.

The intellectual buy-in or business case to change for the transformation is very apparent for Repso, but what about emotional buy-in, sense of urgency and employees' hearts and minds?

\section{Research Objectives}

The paper has five main objectives:

1. To determine the significant relationship between neuroticism and the sense of urgency.

2. To determine the significant relationship between extroversion and the sense of urgency.

3. To determine the significant relationship between openness to experiences and the sense of urgency.

4. To determine the significant relationship between conscientiousness and the sense of urgency.

5. To determine the significant relationship between agreeableness and the sense of urgency.

\section{Research Limitations}

The paper addresses the following limitations. Firstly, the use of modified instrument lacks the established knowledge of its validity and reliability within the contexts of the case organization. In order to manage this, the researcher did a prior thorough data preparation and reduction to determine the reliability and valid items. Furthermore, he has minimized the ambiguity by having census study, which focusing on the current scenario.

Secondly, the researcher has no control on who actually responds to the questions. Even though, the online questionnaires are personally addressed and sent directly to the particular personnel, some staffs may delay the response. This may lead to the questions being answered beyond the time frame, which will affect the data entry for the study. However, to mitigate this problem, the researcher made several follow-up calls as a reminder to the respondents in general. 
Thirdly, the research sample represents only single entity and cannot be generalized to the total population. Contradict to the statistical research, which are used to consider whether the findings can be generalized from the sample to the universe, a "weak" form of generalization often associated with case studies is 'naturalistic generalization' (Gomm, Hammersley and Foster, 2000).

\section{Theoretical Underpinning}

It is notable to mention the Kurt Lewin's Theory, as it is the fundamental basis for change theory (Burnes, 2004; Martin et al., 2009; Wrenn, Stevens, and Louden, 2007). Lewin's theory is based on the premise of three stage process. The first stage is termed unfreezing that is revoking employees from the state of inertia and the attempt to dismantle their existing mindset. This is a crucial phase, as it is the first step in the change process. To facilitate this process, Lewin (1951) suggested an injection of a crisis to awaken employees from their existing comfort zone and complacency.

This is further echoed by Kotter (1995) while propagating the importance of sense of urgency as the first vital step in the effort of change. To certain extent, leader may deliberately create major crisis in an organization to trigger the sense of urgency or unfreeze employees mind in accepting the need for an urgent change from the status of inertia. This however, needs to be exercised in caution in order to avoid, a false sense of urgency which can be counter-productive.

The second stage of Lewin's Theory facilitates the actual change which is associated with the period of shocked, confusion and transition. While the employees are aware of the need to change, they do not have clear picture on the end game or on how they will be impacted. This is a period of uncertainty and anxiety lies on each member of the organization. The third stage is called 'freezing' whereby the aim is to fully internalize the change mindset and stabilized the state of anxiety to the previous level. Kohlrieser (2007) supported the freezing theory by asserting that a stable mind would invoke the mindset of supporting change rather than going against it. Management at this stage should be active in explaining the gaps between current statuses to the desired status while convincing employees over the made available enablers to facilitate the change intended. Here again, structured communication becomes imperative.

Critics of Lewin's Theory, however disagree on the concepts of freezing and unfreezing (Stance and Dunphy, 1994; Nelson, 2003). They argued that these steps if not being supported by adequate explanations of the need to change, can have a lasting adverse impact to the organization, particularly on the element of trust. They claimed that Lewin's theory may apply to smaller scales of change that is departmental or functional changes and may not be suitable for massive transformation of an organization. Inducing massive transformation, according to them, will require complex and thorough steps as the external environment is not static while the organization is going through change.

The debates and arguments about the Lewin's theory called for the support of other theories which focus on the sense of urgency, particularly John Kotter's model. Kotter is in concurrence with Lewin's theory that an imperative steps of initiating change is to eliminate the status quo mindset i.e. 'unfreezing' as termed by Lewin. Both of the scholars agree that the viability of the status quo within the present situation must no longer be inherited. Kotter boldly states that in order to sufficiently guarantee a success likelihood of change, $75 \%$ of the current employees must be dissatisfied with status quo.

Our decision in postulating constructs of neuroticism, agreeableness, openness, conscientiousness and Extraversion as independent variables to sense of urgency is 
supported by the Allport's Traits Theory of Personality in which asserted the needs to study the unique personality of individuals as a prediction to their behaviors. The Five Factor Models is an established tool in measuring personality traits rising from vigorous statistical factoring on myriads of individual traits postulated by scholars (McCrae and Costa, 1997).

\section{Theoretical Framework}

The relationship among the various factors (personality traits and sense of urgency) discussed in this literature is depicted in a framework shown in Figure 1 below:

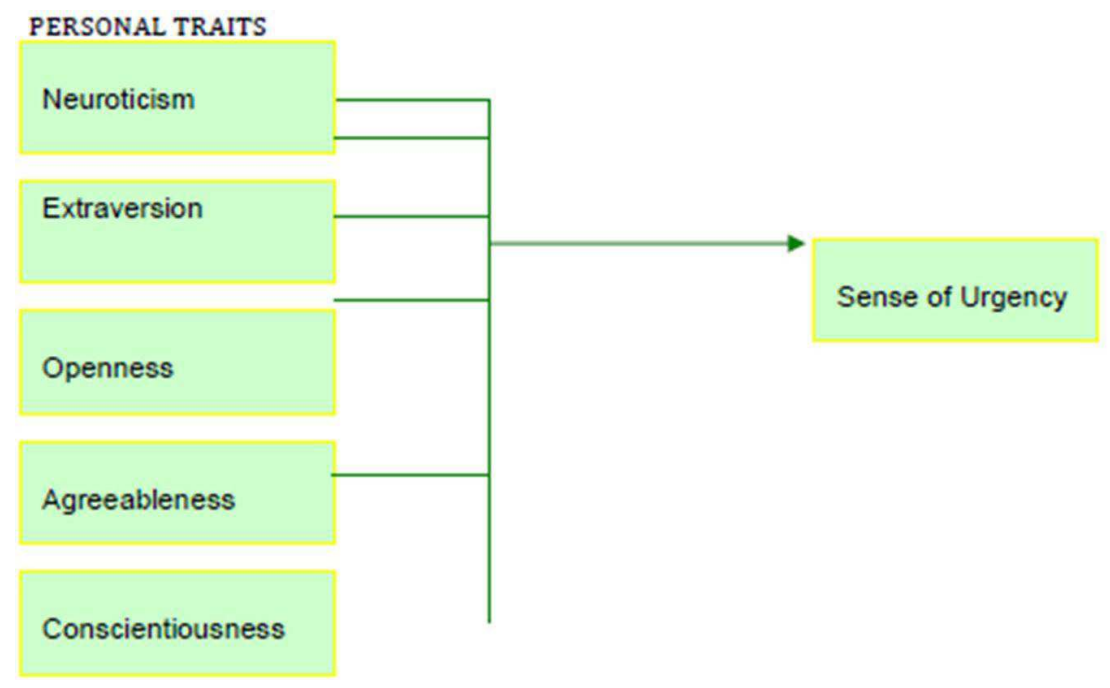

Figure 1: Theoretical Framework

From the literature syntheses, the researcher develops a linkage that an understanding and knowledge of the personality traits are likely to contribute positively or negatively to the sense of urgency. Individual who displays more extraversion, openness, conscientiousness and agreeableness traits is more likely to have greater the sense of urgency. In contrast, individual with neuroticism trait is more likely to have a negative direction to embrace the sense of urgency.

\section{Operational Definitions}

Based on the previous literature review such as Kotter (1996a) on the sense of urgency; Costa and McCrae (1995), Digman (1989) and Barrick, Stewart and Piotrowski (2002) on the personality traits, the researcher has established the operational definitions of all the variables included in the model.

Sense of Urgency is defined as the readiness and motivation to accept and make change works in the mind of employees. It is determined by calculating the sum of the responses by the study participants for each of the items. The higher the sum of sense of urgency, the better prepared the organization is perceived to be in preparing for change.

Neuroticism is the extent to which members of the organization possess the characteristics of anxiety, anger, depression, self-consciousness, impulsiveness and vulnerability.

Extraversion is the extent to which members of the organization possess the 
characteristics of warmth, gregariousness, assertiveness, activity, excitement seeking, and positive emotions.

Openness to Experiences which also been called intellect, or culture is the extent to which members of the organization possess the characteristics of imagination, curiosity, originality, or artistically sensitive.

Agreeableness is the extent to which members of the organization possess the characteristics of trust, straightforwardness, altruism, compliance, modesty, and tendermindedness.

Conscientiousness indicates the quality of an individual towards the job performance. Highly conscientious individuals are typically hardworking, disciplined, and organized, which lead to behaviors that are consistent with on-task process and behaviors.

\section{Research Methodology}

\section{Research Design}

This is a case study which dominantly a deductive approach, while utilizing in tandem the quantitative and cross-sectional approaches. The method of data collection was mainly on survey. The study is focused on operating environment of a MNC which is consistently proactive to change as a part of its survival in sustaining in competitive, turbulent, dynamic and global environment. Case study is being deployed in this research to verify the meaning of the bounded system, hence the outcome is to describe and interpret the case (Vanderstoep and Johnston, 2009).

\section{Case Study and Sampling}

The research context for this case study is Repso Malaysia Sdn. Bhd., The case was defined as the organization as a whole and as a single entity which considered holistic design and type (Yin, 2003). In the case organization, the total population was 247 including the permanent hired and contract employees of the company, which is: 95 at the headquarters at Kuala Lumpur, and 152 personnel at the various plants and regional offices locations. The population is summarized in Table 2.

Table 2: Population of Case Organization

\begin{tabular}{|l|c|}
\hline \multicolumn{1}{|c|}{ Operations } & $\begin{array}{c}\text { Number } \\
\text { of Employees }\end{array}$ \\
\hline Head Quarters & 95 \\
\hline Malaysia Plants and Regional Office & 122 \\
\hline Singapore Plant and Regional Office & 18 \\
\hline Brunei Plant and Regional Office & 12 \\
\hline Total & $\mathbf{2 4 7}$ \\
\hline
\end{tabular}

In meeting the objectives of the theoretical component of this research, the participating MNC was selected. The researcher selected the single case to study according to its potential for helping to expand on or refine the concepts and theory that have already been developed (Yin, 2003; Taylor and Bogdan, 1998).

\section{Online Survey}

A six-page online questionnaire was developed as a research tool for this study. The electronic questionnaire was distributed to the respondents' company e-mail. The questionnaire was designed in a simple manner so that the questions are clear and easy for the respondents to understand. 
Fifty two items obtained from the International Personality Item Pool (IPIP), a combination of previous studies by Costa and McCrae (1992), Matzler et al., (2008), O’Neill and Xiao (2009), Strang and Kuhnert (2009) were used to assess the individual's fivefactor personality. The measurement for personality utilized a five (5)-choice Likert Scale that asked participants to indicate how accurately the statements describes their typical behaviors consistent with neuroticism, extraversion, openness to experience, agreeableness, and conscientiousness. Finally, twenty three (23) items adapted from previous studies by Kahne (2005) and Kotter (2008) were utilized to measure the sense of urgency.

Sekaran (2007) noted that the response rate in a online questionnaire is always low. Therefore, to encourage participation the questionnaire has to be designed to be brief and precise. Due to the long distance, cross border, the researcher had to develop the online survey to be filled-up in a week time, user-friendly, and automatically coded to the Microsoft Office Excel format. After that, the researcher had exported the coding into the quantitative analysis software that is the Statistical Package for the Social Sciences (SPSS) to enable to perform the analysis part.

\section{Data Analysis and Hypotheses Testing}

In order to establish the relationship between the personality traits and the sense of urgency, a multivariate analysis was utilized. The use of it, is the extension of univariate analysis of single-variable distributions) and bivariate analysis (for example the correlation and analysis of variance). The researcher found it is a more complicated analysis setting thus that the multivariate is more appropriate to answer the research questions stated earlier. This is parallel to Hair et al., (2006) and Meyers et al., (2006) who stated that multivariate analysis refers to all statistical techniques that simultaneously analyze multiple measurements on individuals or object under investigation. The analysis provide a system for analysis under conditions in which there may be several independent variables (IVs) and one or many dependent variables (DVs) all correlated with one another to varying degrees.

As stated earlier, data collected from respondents were coded in and compiled using the SPSS software. Normal distribution was established prior to performing further analysis. Reliability test to determine Cronbach Alpha $(\alpha)$ coefficient was performed to establish that a construct could be used with confidence. The range of Alpha coefficient is from 0 to 1 with higher value signifies high confidence in the construct (Hair et al., 2006).

\section{Research Findings}

\section{Demographic Profiles}

The total number of respondents was 232 out of 247 populations. Thus, the overall response rate of this study was $94 \%$. The section describes the demographic profiles including gender, race, qualification, experience, tenure, and position (see Table 3).

Most of the respondents were male (82\%); Malay (44\%); with a higher qualification of Masters' degree (52\%); have working experiences between 5 to 10 years (54\%); having employment between 5 to 6 years (52\%); have 3-4 years in the current position $(61 \%) ;$ and were at the executive/ officer level (60\%). 
Table 3: Respondents' Profile

\begin{tabular}{|c|c|c|c|}
\hline Demographic & & Frequency & Percent (\%) \\
\hline \multirow[t]{2}{*}{ Gender } & Male & 191 & 82 \\
\hline & Female & 41 & 18 \\
\hline \multirow[t]{4}{*}{ Race } & Malay & 102 & 44 \\
\hline & Chinese & 86 & 37 \\
\hline & \begin{tabular}{|l} 
Indian \\
\end{tabular} & 25 & 11 \\
\hline & Other & 19 & 8 \\
\hline \multirow[t]{4}{*}{ Qualification } & Diploma & 30 & 13 \\
\hline & Bachelor & 59 & 25 \\
\hline & \begin{tabular}{|l} 
Masters \\
\end{tabular} & 120 & 52 \\
\hline & Others & 23 & 10 \\
\hline \multirow[t]{4}{*}{ Experience } & $<5$ years & 32 & 14 \\
\hline & 5-10 years & 125 & 54 \\
\hline & $10-15$ years & 65 & 28 \\
\hline & $>15$ years & 10 & 4 \\
\hline \multirow[t]{5}{*}{ Employment } & $<1$ year & 2 & 1 \\
\hline & $1-2$ years & 18 & 8 \\
\hline & 3-4 years & 81 & 35 \\
\hline & 5-6 years & 121 & 52 \\
\hline & $>7$ years & 10 & 4 \\
\hline \multirow{5}{*}{$\begin{array}{l}\text { Position } \\
\text { (year) }\end{array}$} & $<1$ year & 2 & 1 \\
\hline & $1-2$ years & 75 & 32 \\
\hline & 3-4 years & 141 & 61 \\
\hline & 5-6 years & 12 & 5 \\
\hline & $>7$ years & 2 & 1 \\
\hline \multirow[t]{4}{*}{ Position's Held } & Department / Division Head & 15 & 6 \\
\hline & Unit Head & 12 & 5 \\
\hline & Executive/ Officer & 139 & 60 \\
\hline & Others & 66 & 28 \\
\hline
\end{tabular}

In terms of gender, 191 were found to be male $(82 \%)$ and 41 were female $(18 \%)$. Regarding the respondent's race, the vast majority of the respondents 102 (44\%) were Malay, 86 (37\%) were Chinese, 25 (11\%) were Indian and finally $19(8 \%)$ were from other ethnicity. In terms of highest academic qualification, the Diploma accounted for 30 $(13 \%)$ of the respondents, while Bachelor Degree represented 59 (25\%) of the respondents, Masters' degree of 120 (52\%) and finally $23(10 \%)$ of the respondents have other kind of academic qualifications.

In relation to the respondents experience, 32 (14\%) had less than 5 years, whereas 125
(54\%) had between 5 to 10 years of experience, 65 (28\%) had between 10 to 15 years, and finally $10(4 \%)$ had more than 15 years experiences. With regard to the Years of Employment, two (2) identified less than 1 year, $18(8 \%)$ were between 1 to 2 years, whereas $81(35 \%)$ were between 3 to 4 years of employment, 121 (52\%) were between 5 to 6 years, and finally $10(4 \%)$ have been employed for more than 7 years. In terms of duration of current position, two (2) stated less than 1 year, 75 (32\%) were between 1 to 2 years, $141(61 \%)$ were between 3 to 4 years, $12(5 \%)$ were between 5 to 6 years, finally $2(1 \%)$ were more than 7 years. Concerning the Current Position, the 
department or division head accounted for $15(6 \%)$ of the respondents, while unit head represented $12(5 \%)$ of the respondents, executive officer of 139 (60\%) and finally 66 $(28 \%)$ of the respondents were appointed other positions in the company.

\section{Correlation Analysis}

The current research explores the correlation of each variable toward the sense of urgency by using the Pearson's correlation matrix. The correlation coefficients indicate the strength of the association between two variables and the direction of that association (Zikmund, 2007). Based on Hair et al., (2007), the coefficients indicate the strength and direction of a linear relationship between two random variables. In addition, some value in between in all other cases (ranging from -1.0 to +1.0 ), indicating the degree of linear dependence between the variables (Coakes et al., 2006; Hair et al., 2007).
In general, most of the variables had significant positive correlations $(\mathrm{p}<0.01)$ with sense of urgency, except for the neuroticism. Referring to Table 4, the correlation coefficients for the variables under investigation ranged from 0.320 to 0.686 , which indicate the low to moderately high correlations. The conscientiousness was moderately high correlated with SOU $(\mathrm{r}=$ $0.686, \mathrm{p}<0.01$ ), which is also moderately high correlated to the SOU. Then the open to experiences $(r=0.575, p<0.01)$ indicate the moderate correlation to the SOU. the Pearson's correlation coefficients of agreeableness was 0.493 with $r=0.442$ at $p<0.01$. Finally the extraversion of $r=0.320$ at 0.000 (significant level at $\mathrm{p}<0.01$ ) show a low correlation to the SOU. However, the neuroticism showed negative correlation to the SOU (-.047) however it was insignificant results of 0.474 .

Table 4: Pearson's Correlations Matrix for Variables

\begin{tabular}{|l|l|r|r|r|r|r|}
\hline & & Neuroticism & Extraversion & $\begin{array}{c}\text { Openness to } \\
\text { Experience }\end{array}$ & Agreeableness & $\begin{array}{c}\text { Conscientious- } \\
\text { ness }\end{array}$ \\
\hline $\begin{array}{l}\text { Sense of } \\
\text { Urgency }\end{array}$ & $\begin{array}{l}\text { Pearson } \\
\text { Correlation }\end{array}$ & -.047 & $.320\left(^{* *}\right)$ & $.575\left(^{* *}\right)$ & $.442\left(^{* *}\right)$ & $.686\left(^{* *}\right)$ \\
\cline { 2 - 7 } & Sig. (2-tailed) & .474 & .000 & .000 & .000 & .000 \\
\cline { 2 - 7 } & $\mathrm{N}$ & 232 & 232 & 232 & 232 & 232 \\
\hline
\end{tabular}

** Correlation is significant at the 0.01 level (2-tailed).

* Correlation is significant at the 0.05 level (2-tailed).

\section{Multiple Regressions}

This section reports the results of the research objectives of the study. Having established the validity and reliability of the scales, the hypotheses are tested in this section.

From Table 5 the five independent variables (neuroticism, extraversion, openness to experiences, agreeableness, and conscientiousness) together explain $78 \%$ of the dependent variable, i.e. sense of urgency. This means that the model explains $78 \%$ of the variance in sense of urgency which is highly significant (Sig. $=.000$ i.e. $\mathrm{p}<.0005$ ) as indicated by the F-value of 115.826 (see Table 6). 
Table 5: Model Summary for Sense of Urgency and Personality Traits

\begin{tabular}{|l|c|r|r|r|r|}
\hline Model & R & R Square & Adjusted R Square & Std. Error of the Estimate & Durbin-Watson \\
\hline 1 & $.885(\mathrm{a})$ & .784 & .777 & .09878 & 1.805 \\
\hline
\end{tabular}

a) Predictors: (Constant), Neuroticism, Extraversion, Openness, Agreeableness, and Conscientiousness

b) Dependent Variable: Sense of Urgency

In detail, a value of $\mathrm{R}$ square shows a measurement of how much of the variability in the outcome is accounted for by the predictors. Model shows that the value of $\mathrm{R}$ square is 0.784 , which means that predictors accounted for $78 \%$ of the variation in sense of urgency. The adjusted R square gives some idea of how well this model generalizes. Finally, the statistic of the Durbin-Watson shows the assumption of independent error. The value of 1.805 is closer to 2 , which shows that the assumption has almost certainly been met.

Table 6 reveals the analysis of variance (ANOVA) that tests whether the model is significantly better at predicting the outcome than using the mean.

Table 6: Analysis of Variance for Sense of Urgency and Personality Traits

\begin{tabular}{|l|l|r|r|r|r|c|}
\hline & Model & Sum of Squares & \multicolumn{1}{c|}{ df } & Mean Square & F & Sig. \\
\hline 1. & Regression & 7.911 & 7 & 1.130 & 115.826 & $.000(\mathrm{a})$ \\
\hline & Residual & 2.186 & 224 & .010 & & \\
\hline & Total & 10.096 & 231 & & & \\
\hline
\end{tabular}

a) Predictors: (Constant), Neuroticism, Extraversion, Openness, Agreeableness, and Conscientiousness

b) Dependent Variable: Sense of Urgency

Having established the independent and moderating variables significantly collectively explain $78 \%$ of the variance on SOU, the next section sought to explain the relative importance of the various independent variables and moderating variable.

\section{Discussions of Findings}

\section{Discussions}

These sections were discussed the findings of the hypotheses as summarized below in Table 7. 
Table 7: Summary of Findings

\begin{tabular}{|c|l|c|l|}
\hline $\mathbf{H}_{\mathbf{a}}$ & \multicolumn{1}{|c|}{ Hypotheses } & \multicolumn{1}{c|}{ Results } & \multicolumn{1}{c|}{ Explanation } \\
\hline $\mathrm{H}_{1}$ & $\begin{array}{l}\text { Neuroticism is } \\
\text { negatively related } \\
\text { to sense of } \\
\text { urgency }\end{array}$ & Not Confirmed & $\begin{array}{l}\text { Neurotics tend to be high collectivist in their nature - } \\
\text { often highly dependent on the Unions for group } \\
\text { opinions and truly believe that it is the only leverage } \\
\text { for them to protect themselves. }\end{array}$ \\
\hline $\mathrm{H}_{2}$ & $\begin{array}{l}\text { Extraversion is } \\
\text { positively related } \\
\text { to sense of } \\
\text { urgency }\end{array}$ & Confirmed & $\begin{array}{l}\text { Normally extraverts person always enjoy new } \\
\text { environment and also new experience so they tend to } \\
\text { be more responsive to the positive emotions such as } \\
\text { sense of urgency. }\end{array}$ \\
\hline $\mathrm{H}_{3}$ & $\begin{array}{l}\text { Openness is } \\
\text { positively related } \\
\text { to sense of } \\
\text { urgency }\end{array}$ & $\begin{array}{l}\text { Agreeableness is } \\
\text { positively related } \\
\text { to sense of } \\
\text { urgency }\end{array}$ & $\begin{array}{l}\text { Confirmed people who strongly behave openness tend to be } \\
\text { more serious in work environment and increase their } \\
\text { performance. }\end{array}$ \\
\hline $\mathrm{H}_{4}$ & $\begin{array}{l}\text { Conscientiousness } \\
\text { is positively } \\
\text { related to sense of } \\
\text { urgency }\end{array}$ & $\begin{array}{l}\text { Confirmed } \\
\text { The person with high degree of agreeable trait may in } \\
\text { their pursuit of harmonious relations generate more } \\
\text { positive attributions to otherwise provocative } \\
\text { behavior than low-agreeable persons would do. }\end{array}$ \\
\hline $\begin{array}{l}\text { Conscientious individuals who are generally hard } \\
\text { working and reliable would buy the sense of urgency } \\
\text { positively. When taken to an extreme, they may also be } \\
\text { workaholics, perfectionists, and compulsive in their } \\
\text { behavior. }\end{array}$ \\
\hline
\end{tabular}

\section{Hypothesis 1: Neuroticism is Negatively Related to Sense of Urgency}

The results showed neuroticism has no relationship with sense of urgency. One possible explanation for this discrepancy in results might be due to the cross-sectional research design adopted in this study. More specifically, based on the various level of staff surveyed in the research, neurotic trait is more apparent at the lower level staff i.e. plant workers where educational background and external environment awareness are not equitable to the rest.

In investigating this discrepancy, Raja et al., (2004) found neuroticism to be positively related to transactional contracts and negatively related to relational contracts. Transactional contracts are short-term and economic whereas relational contracts are longer-term and socio-emotional in nature (Rousseau, 1995). It can be therefore interpreted that neurotics respond better to immediate needs and is adverse to organization effort to rally them into togetherness in facing long term transformational program. This would further trigger deliberation that neurotic employees are oblivious to sense of urgency as they merit their priority only on shortterm clear reward and security. As they are adverse to uncertainty, they are unable to relate to business case for change and the potential benefits that can be derived from it - particularly if the vision is for longer term. It can be argued that a neurotic would be consistently edgy and vulnerable to both status quo or change circumstances as their priority is short-termed and they refuse to respond to long-term outlook of their career progression and benefit.

They would likely to respond better to transactional leadership whom propagate clear reciprocal performance-reward exchanged methodology. Motivating, coaching and even empathy efforts into them would be meaningless as they lacked sense of belonging and trust on their employer. 
Neurotics tend to be high collectivist in their nature - often highly dependent on the Unions for group opinions and truly believe that it is the only leverage for them to protect themselves. For these reasons, they are not inclined to display significant response towards sense of urgency, structured communication and leadership. Therefore, it explains why neuroticism has no significant effect on sense of urgency, internal communication and moderated by transformational leadership.

\section{Hypothesis 2: Extraversion is Positively Related to Sense of Urgency}

The result from the data collection confirmed that people who traits as extraversion mostly have good sense of urgency. Normally extraverts person always enjoy new environment and also new experience, so, they tend to be more responsive to the positive emotions such as sense of urgency. This is in line with Joyce and Meredith (2007) who found that high degree of extraverts' traits will lead the person to greater sense of urgency. Moreover, their study shows that extraversion traits lead the workers to increase their performance. They tend to be leader for the working environment (Judge et al., 2002).

Bono and Judge (2004) noted that extraverts tend to exhibit inspirational leadership because they are highly intellectual person who love to seek out and enjoy changing process.

\section{Hypothesis 3: Openness is Positively Related to Sense of Urgency}

The results supported that people with high level of openness tend to have a high level of sense of urgency. The people who strongly behave openness tend to be more serious in work environment and increase their performance. They are normally more curious to the working environment (Matzler et al., 2008), introspective (Bono and Judge, 2004) and always related to divergent thinking (Judge et al., 2002). People with high openness react towards the stress or forces or frustration in terms of showing more to sense of urgency.

\section{Hypothesis 4: Agreeableness is Positively Related to Sense of Urgency}

The result supported that there is a positive relationship between agreeableness and the sense of urgency. People with agreeableness trait are described as compliant, soft-hearted and good natured, avoiding tenses and disagreement in the workplace (Costa and McCrae, 1992). Judge and Bone (2004) stated that employees who are high in agreeableness will trust the organization to complete its obligations in the employment bargain. Because of the reciprocal nature of psychological contracts, this trust together with the compliant and cooperative nature of these employees will cause them to do what is necessary to meet the organizations' needs.

Vakola (2004) further described this trait to be less likely in resistance with company's new direction and more likely to adopt a positive attitude to change.

Dijkstra et al., (2004) claimed agreeableness is highly related to pro-social motives, aimed at seeking good outcomes for the person for the group members and to the need for affiliation a recurrent preference in thought and behavior. Results from their studies show that the person with high degree of agreeable trait may in their pursuit of harmonious relations generate more positive attributions to otherwise provocative behavior than low-agreeable persons would do. They may be primarily involved in informal network building as a means to advance their careers at the expense of engaging in productive activities.

Bozionelos (2004) suggested that despite their high performance, agreeable people will not get involved in organizational issues or do anything that might be controversial or 
upsetting to others. Agreeableness will relate to employees' attitudes about their obligations to serve the needs of the job and organization, but there is no reason to believe that agreeableness will relate to employees' obligations to be committed to the job or organization or to be innovative.

\section{Hypothesis 5: Conscientiousness is Positively Related to Sense of Urgency.}

The result supported that there is a positive relationship between conscientiousness and the sense of urgency.

Conscientiousness includes elements such as self-discipline, carefulness, thoroughness, consideration (to think carefully before acting), and need for achievement. Conscientious individuals are achievement oriented, hardworking, and have high expectations of themselves (Barrick, Mount, and Strauss, 1993), which therefore enable them to respond to sense of urgency positively.

Conscientious individuals who are generally hard working and reliable would buy the sense of urgency positively. When taken to an extreme, they may also be workaholics, perfectionists, and compulsive in their behavior. Individuals who are high in conscientiousness are planned, organized, and purposeful, which lead to setting goals (Barrick et al., 1993). People who have on conscientiousness are tending to be more organized and less cluttered in their working environment that make them supported positively the change sense of urgency. Besides that, for those reported high of conscientiousness and high of level empowerment would get more favorable performances rating (Crous et. al., 2007).

\section{Conclusions and Recommendations}

\section{Conclusions}

In conclusion, the findings of this study add to the theoretical framework of many scholars. The immense discussion of organizational change now includes the micro-level study of individual contribution in terms of predicting the level of sense of urgency against existing personality traits.

This research offers an exclusive finding over a study of a single entity which is scarce and the source of limitation from previous studies. The significance of a single entity study serve to validate the theory that sense of urgency need to blanket the entire organization and not tested on random sampling methods.

This research mainly contributes to the body of knowledge in the study of sense of urgency which is relatively in infant stage. The researcher has divided the discussions into the theoretical contribution which encompasses the area of study i.e. the change management and the sense of urgency; followed by the practical contributions which has included the managerial implications and suggested actions to be further expanded.

This research contributes to the stream of change management research and particularly scope to the sense of urgency. It provides further supportive evidences to substantiate the relationship found in previous research relating to the key factors for the sense of urgency. The research was set to find clarity over previous conflicting findings of researches in the same subject and further attempt to overcome the limitations highlighted by the previous researches. Hence, the research findings have contributed to advance the body of knowledge pertaining to the relationship between the personality traits which are diverse and different from individual to another, including neuroticism, extraversion, openness to experience, agreeableness, and conscientiousness to the sense of urgency. It has been asserted by the researcher that the area in which the researcher explored is empirically scarce.

Kotter's studies, while strongly emphasizing the relative importance of sense of urgency, is silent in articulating the physiological 
contribution factors leading to it. We are now suggesting that individual traits at micro level are important prediction to the sense of urgency, thus may contribute to the body of knowledge particularly the future direction of the research in this area.

\section{Recommendations}

Organization goes into an in-depth analysis into the micro level of individual traits of their employees. In doing so, employer would be able to gauge the level of sense of urgency of staff and in return their readiness in embarking in the change journey. Our findings revealed that employee with traits of conscientiousness; openness, agreeableness and extraversion have strong correlation with sense of urgency. On the other hand, leaders need to be tactful in managing employees with the neuroticism trait as it was found negative and inconclusive respectively to sense of urgency.

\section{Future Research}

Future research on sense of urgency may be beneficial, if more items and better measures are developed, in relation to this outcome variable. For instance, to further strengthened the appreciation of personality traits in prediction of sense of urgency, more traits as risk talking, tolerance to ambiguity etc to be added and tested in terms of relationship with sense of urgency.

It would be interesting in future to determine whether constructs like job satisfaction has a proven relationship with sense of urgency.

The limitation inherent in this research is the use of a single case study and thus has limitations in transferring the lesson learned. It was conscious that the decision for the study is to look at a single unit comprising various levels of a function in an organization to change in alignment with the congruence model. It would be interesting if future research can extend the research into multiple companies undergoing changes for more holistic findings.

Replicating and expanding this research effort into non-profit organization, governmental set-up etc as examples should be done to validate the relationship between personality traits and the sense of urgency.

Finally, there is also a merit to examine the same relationships with an organization of a different culture as to determine whether there is a cultural biasness in generalizing our findings to the general population.

\section{References}

Ahmad, H., Francis, A. \& Zairi, M. (2007). "Business Process Reengineering: Critical Success Factors in Higher Education," Business Process Management Journal, 13(3): 451-469.

Allen, S. L. (2007). "Transformational Leadership, Change Readiness and Creativity," Doctoral Thesis, San Jose State University.

Armenakis, A. A. \& Bedeian, A. G. (1999). "Organizational Change: A Review of Theory and Research in the 1990s," Journal of Management, 25(3):293-315.

Armenakis, A. A. \& Harris, S. G. (2002). "Crafting a Change Message to Create Transformational Readiness," Journal of Organizational Change Management, 15(2): 169-183.

Armstrong-Stassen, M. (1998). "The Effect of Gender and Organizational Level on How Survivors Appraise and Cope with Organizational Downsizing," Journal of Applied Behavioral Science, 34: 125-42.

Bacon, T. R. (2003). "Helping People Change," Industrial and Commercial Training, 35(2): 73-77. 
Balogon, J. (2007). "The Practice of Organizational Restructuring: From Design to Reality," European Management Journal, 25(2): 81-91.

Barrick, M. R. \& Mount, M. K. (1991). “The Big Five Personality Dimensions and Job Performance: A Meta-Analysis," Personnel Psychology, 44: 1-26.

Barrick, M. R., Mount, M. K. \& Strauss, J. P. (1993). "Conscientiousness and Performance of Sales Representatives: Test of the Mediating Effects of Goal Setting," Journal of Applied Psychology, 78(5): 715-722.

Bass, B. M. (1985). Leadership and Performance beyond Expectations, New York: The Free Press.

Bass, B. M. (1990). "From Transactional to Transformational Leadership: Learning to Share the Vision," Organizational Dynamics, 18(3):19-32.

Belasco, J. (1990). 'Enlist Champion Change Agents,' Executive Excellence, 7(8): 9.

Bono, J. E. \& Judge, T. A. (2004). "Personality and Transformational and Transactional Leadership; A Meta-Analysis," Journal of Applied Psychology, 89(5): 901-910.

Bono, J. E. \& Vey. M. A. (2007). "Personality and Emotional Performance: Extraversion, Neuroticism, and Self-Monitoring," Journal of Occupational Health Psychology, 12 (2): 177192.

Bordia, P., Jones, E., Gallois, C., Callan, V. \& Difonzo, N. (2006). "Management are Aliens! Rumors and Stress during Organizational Change," Group and Organization Management, 31(5): 601-621.

Burnes, B. (2004). "Kurt Lewin and the Planned Approach to Change: A Reappraisal," Journal of Management Studies, 41(6): 9771002.
Clark, T. R. (2007). Epic Change: How to Lead Change in the Global Age, San Francisco, CA: John Wiley and Sons, Inc.

Coakes, S. J., Steed, L. \& Dzidic, P. (2006). 'SPSS Version 13.0 for Windows: Analysis without Anguish,' Milton Qld: John Wiley and Sons Australia.

Cole, M. S., Harris, S. G. \& Bernerth, J. B. (2006). "Exploring the Implications of Vision, Appropriateness, and Execution of Organizational Change," Leadership and Organization Development Journal, 27(5): 352-357.

Costa, P. \& McCrae, R. (1992). 'NEO PI-R Professional Manual, Psychological Assessment Resources,' Odessa, FL.

Covington, J. (2001). 'Leading Successful, Sustainable Change,' Executive Excellence. Dec: 15-16.

Cummings, T. G. \& Worley, C. G. (2004). Organization Development and Change, Belmont, CA: Thomson Wadsworth.

De Vries, R. E., Roeb, R. A. \& Taillieuc, T. C. B. (2002). "Need for Leadership as a Moderator of the Relationships between Leadership and Individual Outcomes," The Leadership Quarterly, 13: 121-137.

Dijkstra, M. T. M., van Dierendonck, D., Evers, A. \& De Dreu, C. K. W. (2004). "Conflict and Well-Being at Work: The Moderating Role of Personality," Journal of Managerial Psychology, 20(2): 87-104.

George, A. L. \& Bennett, A. (2005). 'Case Studies and Theory Development in the Social Sciences,' Cambridge, MA: MIT Press.

Hair, J. F. Jr., Black, W. C., Babin, B. J., Anderson, R. E. \& Tatham, R. L. (2006). 'Multivariate Data Analysis,' New Jersey: Prentice Hall. 
Hair, J. F. Jr., Money, A. H., Samouel, P. \& Page, M. (2007). 'Research Methods for Business,' New Jersey: Wiley.

Herscovitch, L. \& Meyer, J. P. (2002). "Commitment to Organizational Change: Extension of a Three-Component Model," Journal of Applied Psychology, 87 (3): 474487.

Hertog, F. D., Iterson, A. V. \& Mari, C. (2010). "Does HRM Really Matter in Bringing about Strategic Change? Comparative Action Research in Ten European Steel Firms," European Management Journal, 28: 14- 24.

Higgs, M. \& Rowland, D. (2001). 'Building Change Leadership Capability: The Quest for Change Competence,' Journal of Change Management, 45: 19-22.

Hoyle, D. (2010). 'Managing Processes Effectively (A New Model for Managing Processes),' Quality World, 36(3): 32-36.

Judge, T. A. \& Bono, J. E. (2000). "Five-Factor Model of Personality and Transformational Leadership," Journal of Applied Psychology, 85(2): 751-65.

Judge, T. A., Bono, J. A., Ilies, R. \& Gerhardt, M. W. (2002). "Personality and Leadership: A Qualitative and Quantitative Review," Journal of Applied Psychology, 87(4), 765-780.

Judge, T. A., Heller, D. \& Mount, M. K. (2002). "Five-Factor Model of Personality and Job Satisfaction: A Meta-Analysis," Journal of Applied Psychology, 87(3): 530-541.

Judge, T. A., Higgins, C. A., Thoresen, C. J. \& Barrick, M. R. (1999). "The Big Five Personality Traits, General Mental Ability, and Career Success across the Life Span," Personnel Psychology, 52(3): 621-652.

Kahne, J. D. (2005). 'Measuring the Sense of Urgency: The Leadership Challenge,' Ph.D Dissertation. Our Lady of the Lake University.
Kilpatrick, A. O. (1999). "When in Doubt, Don't," Management, 2: 209-219.

Kohlrieser, G. \& Shreiber, N. (2007). "Take Charge of Your Career Transitions," Perspective for Managers, 27: 1-4.

Kotter, J. P. (1990). A Force for Change: How Leadership Differs from Management, New York: The Free Press.

Kotter, J. P. (1995). Leading Change: Why Transformation Efforts Fail, Harvard Business Review, 73(2): 59-67.

Kotter, J. P. (1996a). Leading Change, Boston MA: Harvard Business School Press.

Kotter, J. P. (1996b). 'Successful Change and the Forces that Drive it,' Canadian Manager, 21(3): 20-23.

Kotter, J. P. (2008). A Sense of Urgency, Boston, MA: Harvard Business School Publishing.

Kotter, J. P. \& Cohen, D. S. (2002). The Heart of Change: Real Life Stories of How People Change Their Organizations, Boston, MA: Harvard Business School Press.

Kotter, J. P. \& Margolis, H. (1996). 'Kill Complacency,' Fortune, 134(3): 168-170.

Lewin, K. (1973). A Dynamic Theory of Personality, New Jersey: McGraw Hill.

Martin, K. D., Johnson, J. L. \& Cullen, J. B. (2009). "Organizational Change, Normative Control Deinstitutionalization, and Corruption," Business Ethics Quarterly, 19(1): 105-130.

Matzler, K., Renzl, B., Müller, J., Herting, S. \& Mooradian, T. (2008). "Personality Traits and Knowledge Sharing," Journal of Economic Psychology, 29: 301-313. 
McCrae, R. R. \& Costa, P. T. (1997). "Personality Trait Structure as a Human Universal," American Psychologist, 52: 509516.

Merriam-Webster. (2003). 'Collegiate Dictionary (11th ed.),' Springfield, MA: Merriam-Webster.

Meyers, L. S., Gamst, G. et al. (2006). 'Applied Multivariate Research: Design and Interpretation,' London:mSage Publication.

Miller, D. (2002). "Successful Change Leaders: What Makes Them? What Do They Do Different?," Journal of Change Management; 2(4): 359-368.

Mitchell, M. \& Jolley, J. (1992). 'Generating the Research Hypotheses: Tapping Intuition, Theory and Existing Research,' Journal of Clinical Neuroscience, 15(2): 37-90.

Mowen, J. C., Park, S. \& Zablah, A. (2007). "Toward a Theory of Motivation and Personality with Application to Word-ofMouth Communications," Journal of Business Research, 60: 590-596.

Nadler, D. A. \& Tushman, M. L. (1980). “A Model of Diagnosing Organization Behaviour," Organizational Dynamics. 4: 3539.

Nelson, L. (2003). "A Case Study in Organizational Change: Implications of Theory," The Learning Organization, 10: 1830.

Nikolaou, I. (2003). "Fitting the Person to the Organization: Examining the Personality-Job Performance Relationship from a New Perspective," Journal of Managerial Psychology, 18(7/8): 639-648.

O’Neill, J. W. \& Xiao, Q. (2009). 'Effects of Organizational/ Occupational Characteristics and Personality Traits on Hotel Manager Emotional Exhaustion,' International Journal of Hospitality Management, 10(1): 12-24.
Paton, B., Beranek, L. \& Smith, I. (2008). "The Transit Lounge: A View of Organizational Change from a Point in the Journey," Australia Library Management. 29(1): 87103.

Raineri, A. B. (2011). "Change Management Practices: Impact on Perceived Change Results," Journal of Business Research.

Raja, U., Johns, G. \& Ntalianis, F. (2004). “The Impact of Personality on Psychological Contracts," Academy of Management Journal, 47(3), 350-367.

Roth, M. \& Collani, G. V. (2007). "A Head-toHead Comparison of Big-Five Types and Traits in the Prediction of Social Attitudes," Journal of Individual Differences, 17: 27-31.

Russell, J. L. \& Russell, L. (2006). Change Basics, Alexandria, VA: American Society for Training and Development.

Salgado, J. F. (2003). "Predicting Job Performance with FFM-Based and non-FFMBased Personality Inventories," Journal of Occupational and Organizational Psychology, 76, 323-346.

Sekaran, U. (2007). 'Research Methods for Business: A Skill Building Approach (8th ed.),' New York: John Wiley and Sons Ltd.

Stanleigh, M. (2008). "Effecting Successful Change Management Initiatives," Industrial and Commercial Training, 40(1): 34-37.

Strang, S. E. \& Kuhnert, K. W. (2009). "Personality and Leadership Developmental Levels as Predictors of Leader Performance," The Leadership Quarterly, 20: 421-433.

Sutherland, R., De Bruin, G. P. \& Crous, F. (2007). "The Relation between Conscientiousness, Empowerment and Performance," Journal of Human Resource Management, 5 (2): 60-67. 
Tallman, R. R. J. \& Bruning, N. S. (2008). “Relating Employees' Psychological Contracts to Their Personality," Journal of Managerial Psychology, 23(6): 688-712.

Taylor-Bianco, A. \& Schermerhorn, J. (2006). "Self Regulation, Strategic Leadership and Paradox in Change," Journal of Organizational Change Management. 72: 12-18.

Toback, S. (2009). 'Most Merger Fails: So Why Do Them?,' Bnet. The CBS Interactive Business Network.

Taylor, S. J. \& Bogdan, R. (1998). Introduction to Qualitative Research Methods: A Guide and Resource, New York: John Wiley and Sons, Inc.

Todnem, R. (2007). "Ready or Not," Journal of Change Management. 7(1): 3-11.

Vakola, M., Tsausis, I. \& Nikolaou, I. (2004). "The Role of Emotional Intelligence and Personality Variables on Attitudes towards Organizational Change," Journal of Managerial Psychology, 19(1/2): 88-110.

Vanderstoep, S. W. \& Johnston, D. D. (2009). Research Methods for Everyday Life: Blending Qualitative and Quantitative Approaches, New Jersey: Wiley.

Walker, H. J., Armenakis, A. A. \& Berneth, J. B. (2007). "Factors Influencing Organizational Change Efforts: An Integrative Investigation of Change Content, Context, Process and Individual Differences," Journal of Organization Change Management, 20(6): 761-773.

Woerkum, C. M., Aarts, M. N. \& Grip, K. (2009). 'Creativity, Planning and Organizational Change,' Journal of Organization Change Management, 20(6): 761-773.

Yin, R. (2003). Case Study Research - Design and Methods, New Jersey: SAGE Publications. 